\title{
PERUBAHAN SISTEM HUKUM MENUJU JATI DIRI SEBUAH NEGARA
}

\author{
Emy Hajar Abra \\ Dosen Fakultas Hukum Universitas Riau Kepualuan Batam \\ my_87_hjf@yahoo.com
}

\begin{abstract}
Legal system of a state determine the main source of law in making a legal policy, clearly legal systems has certain characteristic although on the development differences among legal system cannot be seen clearly. To comprehend and strengthen the legal systemof a staterequired an observation toward legal system of other states as comparison. The function of legal systems comparison is the basis to grouping states into the family of legal system. Basically legal system describes legal form of a state, hence when a legal system createdfrom structure, substance and culture of certain state the legal system must reflect the state identity. Several factors influence the process to develop a legal system, such as economics, political and social. Means, legal system could be form not only by internal values but also external factorsof state. As a result to avoid legal systems with thin similarities and differences, finding a suitable legal system that in line with the identity of a country is a better way.

Discussion about the thin differences between Continental European and Anglo-Saxon do not get big attention as before, impressed ignored and turn out trigger of questions. Why a stateunable to consistently espoused the legal system?, whethergrouping legal systemsinto family of legal system no longer important?. This paper will answer those question by deeply examinethe restoration of legal system so that in line with the historical value of a state. Colonized states often apply legal system that comes from colonizer after independent which means their legal system is notthe state pure legal system that can be incompatible with the values that develop in a state. Would be inconsistent when the legal system applied is Continental European, but in fact the values, laws, institutions and legal verdict are based on the values of religious, Islam for instance.

Gambia, a state in Africa with 95\% of population is Muslim and the former British colonytake a big step by leave the legacy of colonial legal system, Anglo-Saxon. Gambia. How could a state forced to follow the legal systems of other states remember law is an independent rule, free from interference and coercion. This is the focus study will explain about that when legal system with openness value must have consistency with values that recognizedand upheld by society in a state. As a result changes in a legal system toward identity of a country are necessity and inevitable. On the other hand, debates and critics on the thin differences of legal system should be an independent study to discuss.
\end{abstract}

Keyword: legal system, identity, state.

\begin{abstract}
Abstrak
Sistem hukum suatu negara menentukan sumber hukum pertama dalam membuat sebuah kebijakan hukum. Sistem hukum sendiri memiliki ciri khas tertentu walaupun kemudian antara beberapa sistem hukum kini mengalami perbedaan yang cukup tipis. Dalam hal mengetahui sistem hukum sebuah negara, maka yang dilakukan untuk menguatkan sistem hukum adalah dengan melihat sistem hukum negara lain. Perbandingan sistem hukum inilah yang kemudian dikaji untuk melihat pengelompokkan negara dalam keluarga sistem hukum nantinya.
\end{abstract}


Sistem hukum sejatinya menggambarkan bentuk hukum pada suatu negara, oleh karenanya ketika sebuah sistem hukum lahir dari stuktur, substansi dan kultur, maka sistem hukum pada suatu negara haruslah mencerminkan jati diri negara tersebut. Lahirnya sistem hukum dipengaruhi oleh banyak faktor, seperti ekonomi, politik dan sosial. Artinya bahwa sistem hukum bisa jadi lahir karena faktor-faktor eksternal, bukan nilai-nilai internal dari negara itu sendiri. Maka untuk menepis tipisnya persamaan dan perbedaan sebuah sistem hukum, akan lebih baik mencari sistem hukum yang sesuai dan sejalan dengan jati diri sebuah negara.

Kini perbincangan tentang tipisnya perbedaan Eropa Continental dan Anglo Saxon sudah masuk pada ranah yang diabaikan. Pertanyaan besarnya kemudian adalah, kenapa sebuah negara sudah tidak mampu konsisten akan sistem hukum yang dianutnya? atau apakah sistem hukum sudah menjadi hal yang tidak penting lagi untuk dikelompokkan menjadi keluarga sistem hukum? Inilah yang akan diangkat dalam tulisan nantinya, yakni mengembalikan sistem hukum agar sesuai dengan nilai historis sebuah negara. Sistem hukum yang dijalankan hanya karena bekas jajahan adalah bukan sistem hukum murni negara tersebut, karena sistem hukum yang diterapkan bisa jadi tidak sesuai dengan nilai-nilai yang berkembang pada suatu negara. Akan menjadi inkonsistensi ketika sistem hukum yang digunakan adalah eropa continental, tapi kenyataannya nilai yang berkembang, hukum yang diterapkan, lembaga yang dijalankan dan dijadikan keputusan hukum adalah nilai-nilai religiusitas dalam hal ini misalnya Islam.

Contohnya Turki, Gambia dan Indonesia adalah memiliki sistem hukum yang berbedabeda. Gambia misalnya, negara 95\% Muslim berani memisahkan diri dari bekas Kolonial yang sudah cukup lama bertengger dalam sistem hukum negara tersebut, yakni Anglo Saxon. Gambia lama dijajah Inggris dan kemudian masuk dalam persemakmuran Inggris dan berada dibawah kekuasaan Ratu Elizabet. Bagaimana mungkin sebuah negara dipaksakan mengikuti sistem hukum negara lain? Bukankah hukum adalah sebuah aturan yang mandiri. Bebas dari campur tangan dan pemaksaan. Hal inilah kemudian yang akan dikaji, bahwa ketika sebuah sistem hukum bernilai terbuka, maka sistem hukum harus memiliki konsistensi dengan nilai yang diakui dan dijunjung oleh masyarakat pada sebuah negara. Oleh karenanya perubahan sebuah sistem hukum menuju jati diri sebuah negara adalah keniscayaan dan tidak bisa dielakkan. Bahwa semakin tipisnya nilai perbedaan sebuah sistem hukum menjadi kritikan sebagai bahan kajian kelimuan hukum tersendiri yang patut diangkat.

Katakunci: Sistem Hukum, Jati Diri, Negara.

\section{A. LATAR BELAKANG}

Sebelum berbicara mengenai sistem hukum, maka akan lebih tepatnya berbicara tentang sistem norma terlebih dahulu. Karena sistem hukum mempengaruhi tatanan putusan hukum sebuah negara, maka sistem hukum tidak akan pernah terlepas dengan "sistem norma", karena norma adalah bagian dari nilai-nilai hukum yang hidup sesuai pada pengakuan kehidupan bermasyarakat dan bernegara. Nilai-nilai pada norma itu hadir dan berkembang begitu saja disuatu negara tanpa keharusan untuk disahkan atau tidak. Sistem Norma dapat menjadi salah satu bagian bahkan dasar dari sebuah sistem hukum. Maka Sistem hukum adalah sistem norma. Sistem dimaknai sebagai suatu kesatuan yang bersifat kompleks, yang terdiri dari bagian-bagian yang terhubung satu sama lain, sedangkan hukum menurut S.M. Amin, S.H adalah kumpulan peraturan yang terdiri dari norma dan sanksi, dengan tujuan mewujudkan ketertiban dalam pergaulan manusia.

Sistem norma yang berlaku bagi manusia dalam bernegara sekurangnya terdiri dari 4 (empat) unsur norma, yakni: ${ }^{1}$

a. Norma moral adalah sistem aturan yang berlaku bagi manusia yang bersumber

1 Sistem Hukum Indoneisa, 2004, Prinsip-Prinsip Dan Implementasi Hukum Di Indoensia, Ilham Bisri, Pt Raja Grafindo Persada, Jakarta, hlm. 5 
dari setiap hati manusia atau yang sering disebut juga dengan hati nurani yang bekerja atas dasar kesadaran setiap manusia terhadap sekelilingnya.

b. Norma agama adalah sistem aturan yang diperoleh manusia berdasarkan ajaran agama yang dianutnya, sumber norma agama berasal dari ajaran Tuhan yang diperoleh atau yang diturunkan dan disebarluaskan melalui Nabi dan RosulNya.

c. Norma etika atau norma sopan santun adalah sistem aturan hidup manusia yang bersumber dari kesepakatan atau consensus yang diciptakan oleh suatu komunitas masyarakat pada suatu wilayah tertentu, pada masyarakat yang masih memiliki adat istiadat yang kental hukuman pembuangan atau pengucilan bisa diberikan kepada pelanggar norma etika setempat.

d. Norma hukum adalah sistem aturan yang diciptakan oleh lembaga kenegaraan yang ditunjuk melalui mekanisme tertentu, artinya hukum diciptakan dan diberlakukan oleh intitusi yang memang memiliki kompetensi atau kewenangan dalam membentuk dan memberlakukan hukum yaitu badan legistlatif.

Pada tahun 1900 dalam hukum komparatif internasional pertama dikelompokkanlah klasifikasis sistem hukum ke dalam 5 (lima) keluarga hukum: Romanistik, Jermanitik, Anglosaxon, Slavik, Islamik. Kemudian tahun 1977, Zweigert An Kotz membagi dalam 8 (delapan) diantaranya: Romanistik, Jermanistik, Nordik, Camman Law, Sosialis, Sistem Timur Jauh, Hukum Islam, Hukum Hindu. Pada 1978 David dan Brerley mengadopis dan menjadikannya sebagai Romano, Gemanik, Camman Law, Sosilaistik, Islamik, Hindu, Yahudi, Timur Jauh, Afrika Hitam.

Sampai sekarang kita hanya mengenal 4 (empat) sistem hukum yang masih bertahan dan populer, yakni: Sistem Hukum Eropa Continental, Sistem Hukum Anglo Saxon, Sistem Hukum Adat dan Sistem Hukum Islam. Prof. Dr. Jan Michiel Otto mengatakan bahwa perbedaan antara Common Law dan Civil Law di Eropa sudah semakin mengecil. Sistem hukum yang dianut Belanda berada di antara Continental (Civil Law) dan Common Law, bahwa Common Law ada Judge-Made Law (hakim yang membuat hukum), dan Civil Law adalah hukum dibuat oleh legislator. Tapi di sistem Belanda, apa yang dipelajari ketika menjadi mahasiswa juga belajar banyak Case Law (kasus-kasus atau putusan pengadilan). Bagi beberapa orang Indonesia, ketika mereka mendapat beasiswa dan belajar hukum ke Australia, Inggris, Amerika Serikat, lalu mereka kembali. Mereka telah belajar banyak Case Law (putusan pengadilan). ${ }^{2}$ Artinya bahwa kini kelompok keluarga sistem hukum sudah lepas dari sejarah hadirnya sistem hukum itu sendiri, bahwa kini didapati sistem hukum yang satu pada negara lain justru juga menggunakan sistem hukum yang seharusnya bukan pada negara tersebut.

Berbeda dengan sistem hukum Eropa Continental dan Anglo Saxon yang kini bisa dikatakan tipis perbedaannya, sistem hukum adat justru adalah bagian dari sistem hukum yang lebih lama yakni dari masa awal sejarah tatanan kehidupan yang dibentuk hingga selama sistem hukum itu masih diakui dan dikembangkan. Kemudian sistem lain yang juga dirasa menarik dan mampu bertahan dengan ciri khususnya adalah Sistem Hukum Islam, karena sistem hukum ini bersumber dari ajaran agama yang dianggap paling mampu bertahan dari pada agama lain, seperti sebelumnya terdapat sistem hukum Hindu dan Kristen. Sistem hukum Islam adalah salah satu sistem hukum yang mempunyai ciri khusus karena berasal dari ajaran Islam yang bersumber dari Allah dan Sunnah Rosul, dan Ra`yu atau akal.

Akal kemudian digunakan untuk menemukan sebuah hukum Islam, dalam hal ini disebut sebagai ijtihad. ljtihad menurut Abdul Hamid adalah bersungguh-sungguh sekuat-kuatnya untuk mencapai hukum syari'i dengan jalan mengambil hukum dari Al-Quran dan As-Sunnah. ${ }^{3}$ Dalam hal menemukan hukum Islam/ ijtihad,

2 Http://Www.Hukumonline.Com/Berita/Baca/ Lt53a2eb91bd3ce/Prof-Dr-Jan-Michiel-Otto--BrahliHukum-Indonesia-Harus-Sering-Kaji-Putusan

3 Mardani, 2015, Hukum Islam Pengantar IImu Hukum Islam Di Indoensia, Pustaka Pelajar, Yogyakarta, hlm. 141. 
maka digunakanlah beberapa metode penemuan hukum Islam, seperti ljma, Qiyas, dan lain-lain. Dalam mengkaji perbandingan sistem hukum khususnya sistem hukum Islam, maka penulis mengambil beberapa contoh negara-negara di dunia, seperti Turki, Gambia dan Indonesia.

Sistem hukum Islam tidak mudah ditemukan pada suatu Negara secara terang-terangan, namun sistem hukum ini dapat dikatakan bertahan dengan penggunaannya secara pelan dan tersembunyi. Bagaimana tidak, negara-negara di dunia pada saat berada di dalam penguasaan suatu negara, tapi negera penguasa tersebut secara tidak langsung memaksakan negara jajahannya untuk menggunakan sistem hukum mereka. Sekalipun sejarah, populasi serta hukum tidak tertulis yang digunakan adalah mengikuti ajaran penduduk atau adat suatu negara. Contohnya Gambia, begitupun dengan negara Turki. Turki pada awalnya adalah bekas kekuasaan otoriter kemalis dengan bantuan militer untuk menjadi Negara Islam sekuler dengan sistem hukum Eropa Continental, namun kini Turki mengembalikan nilai-nilai sejarah Turki Usmani dengan sistem kholifah yang sempat dihilangkan oleh barat dan sejarah. Turki mencoba secara perlahan kembali menghadirkan hukum Islam dalam negara Turki, ini artinya secara tidak langsung Turki ingin menghilangkan sistem Eropa Continental dan menggantikannya dengan Sistem Hukum Islam, hal ini bisa dilihat dari perubahan konstitusi yang dilakukan oleh negara tersebut setelah Mustafa Kemal digantikan. Lalu dapatkah perubahan sistem hukum mengembalikan jati diri sebuah negara?

\section{B. METODE PENELITIAN}

Paradigma yang digunakan dalam kajian penulisan ini adalah Paradigma konstruktivisme, yang berangkat dari keyakinan bahwa realitas itu beragam. Konstruktivisme memahami kebenaran realitas bersifat relatif, berlaku sesuai dengan konteks spesifik yang relevan dengan pelaku sosial. Penelitian ini adalah penelitian doktrinal, penelitian ini juga sekaligus merupakan penelitian non doktrinal. Sebagaimana diuraikan di atas bahwa sebagai penelitian non doktrinal, penelitian ini bersifat deskriptif. Sebagai penelitian yang bersifat deskriptif, maka analisa data yang digunakan adalah dengan cara analitis, sehingga cara analisis datanya disebut dengan cara deskriptif analitis.

Deskriptif analitis adalah penelitian yang disamping memberikan gambaran secara rinci, menuliskan dan melaporkan suatu obyek atau suatu peristiwa juga akan mengambil kesimpulan umum dari masalah yang dibahas. ${ }^{4}$ Data yang terkumpul dari hasil penelitian ini dianalisa secara deskriptif kualitatif, yaitu data-data yang diperoleh dalam penelitian tersebut digambarkan dan ditata secara sistematis dalam wujud uraianuraian kalimat yang diambil maknanya sebagai pernyataan atau kesimpulan. ${ }^{5}$

\section{PEMBAHASAN}

Sistem hukum adalah sebuah ilmu hukum umum yang sifatnya cukup istimewa, hal ini karena sistem hukum adalah bagian dari sebuah tatanan dalam pembentukan sebuah negara dan aturan hukum yang ada di dalamnya. Dalam hal mengenal sistem hukum maka kajian lain yang harus dilakukan untuk membandingkan dan mencari perbedaan serta persamaan pada negara lain, maka dilakukanlah ilmu perbandingan hukum khususnya mengenai sistem hukum. Secara umum sistem hukum atau tatanan hukum diartikan sebagai sebuah sistem dari keseluruhan kaidah-kaidah hukum dan bentuk penampilanya dalam aturan-aturan hukum. Sistem hukum merupakan suatu sistem terbuka yang harus mampu mengakomodasi perkembangan yang terjadi dalam masyarakat. ${ }^{6}$ Faktor apa yang berpengaruh dan dianggap relevan bagi terbentuknya sistem hukum sangat ditentukan oleh nilai ideologis pengguna metode pembandingan itu sendiri. Contoh seorang marxis akan berpandangan secara tegas mengenai hubungan diantara sistem hukum produksi dan sistem hukum tersebut cendrung lebih mementingkan sistem ekonomi dari pada sosialis idealis. Seorang rasis akan percaya bahwa ras penduduklah yang menetukan segala aspek

4 Soerjono Soekanto, 2005, Pengantar Penelitian Hukum, UI Press, Jakarta, hIm. 32.

5 Rony Hanitijio Soemitro, 1998, Metodologi Penelitian Hukum Dan Juri Metri, Ghalia, Jakarta, hlm. 82.

6 Sistem Hukum Indoneisa, 2004, Prinsip-Prinsip Dan Implementasi Hukum Di Indoensia, Ilham Bisri, Pt Raja Grafindo Persada, Jakarta, hlm. 5 
dalam kehidupan masyarakat. ${ }^{7}$

Faktor-faktor yang mempengaruhi dalam terbentuknya sebuah sistem hukum: ${ }^{8}$

1. Sistem ekonomi

Kebutuhan akan aturan hukum yang melindungi terhadap praktik bisnis sebenarnya baru muncul ketika ekonomi pasar menyebabkan timbulnya pemusatan kekuatan ekonomi sampai taraf tertentu.

2. Ideologi dan sistem politik

Sistem hukum sangat dipengaruhi oleh sistem politik negara. Ada hubungan kuat antara sistem politik dan sistem ekonomi suatu negara di satu isi dengan ideologi yang bertahta di sisi yang lain.

3. Agama

Sikap dan keyakinan agama populasi dapat berperan penting bagi sistem hukum. Contoh sebuah negara yang didominasi umat Kristen akan kesulitan menerima poligami dan sementara muslim sebaliknya. Contoh lain tentang alkohol.

4. Sejarah dan geografi

Sistem hukum terbentuk di bawah pengaruh kuat perkembangan sejarah negaranya. Pada negara-negara tertentu peninggalan dari sebuah sejarahlah yang menentukan sebuah sistem hukum yang berlaku bagi negaranya, walaupun akhirnya banyak adaptasi atau kearifan lokal setelah sekian lama dijajah.

5. Faktor demografi

Umat manusia bisa dibagi menjadi beberapa ras dan etnis yang seringkali pula latar belakarang sejarahnya, walaupun keadaan yang demikian sudah berangsur dipulihkan dengan perpolitikan antara negara yang ikut mengahapusnya.

6. Faktor kebetulan dan tak dikenal Sama halnya dengan demografi hal ini sudah berangsur tidak diakui, walaupun pada sejarahnya hukum kekeluargaan lahir atas inisiatif Napoleon. Selain itu unsurunsur tidak sengaja yang terjadi atas sebuah kepentingan membuat negara tersebut harus membuat kebijakan tersendiri.

7 Ibid., hlm. 80

8 Michael Bogdan, 2010, Pengantar Penbandingan System Hukum, Nusamedia, Bandung, hlm. 88.
Berikut adalah sistem hukum dari berbagai negara, yaitu sebagai berikut:

\section{Turki}

Pada tanggal 1 November 1922 Dewan Agung Nasional pimpinan Mustafa Kemal menghapuskan kekhalifahan. Akhirnya Dewan Nasional Agung pada tanggal 29 Oktober 1923 memproklamasikan terbentuknya negara Republik Turki dan mengangkat Mustafa Kemal sebagai Presiden Republik Turki.Hukum keluarga yang sudah ada sebelumnya dengan Mazhab Hanafi dirubah dengan sistem sekuler, yang diimplementasikan dalam beberapa undang-undang, seperti pada pertunangan, batas usia kawin, poligami, pencatatan perkawinan, pembatalan perkawinan, perceraian, dan lain-lain.

Melalui sekularisasi hukum keluarga dihapuskan dan diberlakukan UndangUndang perdata Swiss dan Undang-Undang pidana Italia. Sedangkan dalam hukum pidana melarang adanya pembentukan perkumpulan berbasiskan agama. Mengenai kementerian Agama dan Perwakafan, juga diganti dengan Direktorat Jenderal yayasan keagamaan. Di sini terlihat bahwa untuk pemberlakuan hukum keluarga Islam harus dikontrol melalui negara. ${ }^{9}$ Ini terbukti melalui disertasi Adian Husaini yang menjelaskan bahwa tahun 1937 prinsip sekularisme dimasukkan kedalam konstitusi Turki. Dalam soal perkawinan, hukum perkawinan tidak lagi dilakukan sesuai dengan syari'at islam, tetapi dilakukan sesuai dengan hukum sipil (civil code) yang diadopsi dari Swiss (Swiss civil code)pemerintah mengeluarkan kebijakan mengganti pengucapan adzan ke dalam bahasa Turki, dan pelarangan jilbab secara konstitusional baru terjadi pada tahun $1998 .^{10}$

9 Erik J.Zurcher, Turkey, A Modern History, Alih Bahasa Oleh Karsidi Diningrat R, Sejarah Modern Turki,Pt Garmedia Pustaka Utama, Jakarta, 2003, HIm. 242243

$10 \mathrm{Http}: / /$ Syafiqie-Imam.Blogspot.Co.Id/2015/03/HukumKeluarga-Islam-Di-Turki-By-Imam-A.Html, Diakses Pada Tanggal 15 Desember 2015 
Sejarah Turki adalah sejarah peradaban Islam yang cukup lama, dalam sistem negara yang dipimpin oleh seorang kholifah Islam di Turki Berjaya dan berpengaruh. Pada masa itu Sistem Hukum Turki jelas hanya bersumber dari Islam, yakni AI Quran Sunnah dan Akal (qiyas, ijma, dan lain-lain). Sistem itu jelas berpengaruh pada sistem ketatanegaraan dalam hal ini lembaga-lembaga hukum yang digunakan, kehidupan masyarakat Turki hanya dibentengi pada hukum Islam semata. Namun hingga akhirnya Turki dikuasai oleh Rezim Sekuler Turki mengalami banyak perubahan yang sangat signifikan, dari ideologi, kehidupan bermasyakarat, hingga pada undangundang bahkan konstitusi yang sama skali menghilangkan nilai Islam di dalamnya dan justru menjauhkan Turki dari Nilai Islam tersebut.

Sistem hukum Turki sebelumnya menggunakan Eropa Continental, beberapa hukum dipaksakan untuk menggunakan Sistem Hukum Eropa dengan mengadopsi hukum Swiss dan Italia. Hal tersebut cukup berpengaruh ketika Turki menjadikan negaranya sebagai negara Islam Sekuler, namun kini Sistem Hukum Eropa Continental tersebut secara perlahan mulai disingkirkan dengan menghidupakan kembali nilai Hukum Islam dan mengarahkan Sistem Hukum Turki ke Sistem Hukum Islam seperti sediakala. UUD beberapakali diamandemen, UU tentang pelarangan ajaran Islam dihapuskan.

\section{Gambia}

Tidak seperti Turki yang secara perlahan menghilangkan nilai-nilai hukum Eropa dalam batang tubuh negaranya, Gambia lebih berani merubah haluan arah sistem hukumnya. Tepat pada minggu 13 desember 2015 lalu, presiden Gambia mendeklarasikan perpindahan ideologi sekaligus arah sistem kenegaraan, dari yang sebelumnya menggunakan Sistem Hukum Anglo Saxon dengan kekuasaan dan kewenangan masih di tangan negara jajahannya kini menjadi menjadi Negara Islam yang secara otomatis merubah sistem hukumnya menjadi Sistem Hukum Islam. Hal perubahan menjadi Negara Islam dengan alasan identitas agama negara dan nilai-nilai, sebagaimana muslim mayoritas di negeri ini, Gambia tidak mampu untuk melanjutkan warisan colonial. ${ }^{11}$

Sebelumnya menurut catatan sejarah yang cukup terbatas, bahwa Gambia memang sangat unik, negara kecil seluas negara bagian Delaware Amerika Serikat, pernah dijajah Portugal, Belanda, Jerman, Perancis dan terakhir adalah Inggris. Bahasa nasional Gambia adalah Inggris. Pada tahun 1820, Gambia dijadikan negara protektorat Inggris, dan pada tahun 1843, menjadi bagian dari koloni Kerajaan Inggris. Lelah dijajah, masyarakat Gambia berhasrat mengurus dirinya sendiri. Tanggal 18 Pebruari 1965 Inggris bersedia memberikan kemerdekaan kepada Gambia, dengan Ratu Elizabeth sebagai Kepala Negara. Jumlah pemeluk Islam di Gambia saat ini adalah 95\% (bukan 90\%) dan pemeluk Kristen hanya 4\%, walaupun presiden Yahya Jammeh seorang muslim, dan Kristen hanya $4 \%-9 \%$, namun dalam pemerintahan Gambia, orang-orang Kristen dapat menduduki jabatan-jabatan strategis. Sebagaimana Senegal, Islam di Gambia beraliran Suni, dan sebagian besar dari mereka menganut paham Sufi. ${ }^{12}$

Selain lama dijajah Inggris, Gambia juga menjadi negara persemakamuran Inggris, dengan demikian jelaslah bahwa hukum-hukum yang diberlakukan adalah hukum dan undang-undang yang digunakan di Inggris, apalagi kepala

11 Http://M.News.Viva.Co.Id/News/Read/710631-AlasanGambia-Jadi-Negara-Islam, Diakses Pada Senin 14 Desember 2015

$12 \mathrm{Https}: / /$ Chamzawi.Wordpress.Com/2008/07/26//slamDi-Gambial, Artikel Tersebut Telah Dimuat Dalam Majalah Amanah No. 57, Th. Xviii, Desember 2004 / Syawal - Dzulqa'dah 1425 H. Diakses Pada Tanggal 14 Desember 2014 
negara pada masa awalnya adalah ratu Elizabeth, hal ini tentu mewajibkan Gambia ikut dan tunduk pada aturan yang dijalankan Inggris. Namun kini Gambia mencoba melepas diri dari sistem Kolonial tersebut, Gambia dengan keterbatasan pada negaranya mencoba berdiri sendiri dengan mendirikan Negara Islam. Deklarasi yang ucapkan Presiden Gambia adalah bagian dari deklarasi penentuan sikap sekaligus jatidiri Gambia, bahwa negara Gambia dapat berdiri dengan sistem hukum asal negaranya yakni Sistem Hukum Islam.

\section{Indonesia}

Indoneisa adalah pengguna sistem hukum campuran, walaupun pernyataan tersebut akan dibantah dengan mengatakan Indonesia hanya menggunakan Sistem Hukum Eropa Continental semata. Sistem hukum Indonesia adalah sistem hukum dengan perpaduan dari 3 (tiga) sistem hukum, yakni Sistem Hukum Eropa Continental, karena Indonesia dijajah belanda sangat lama 350 tahun. Dari sebelum Indonesia merdeka, Belanda sudah memaksakan masyarakat untuk menggunakan Sistem Hukum Belanda (sekalipun terdapat penggolakan hukum di Nusantara), namun beberapa ketentuan undangundang peninggalan Belanda itu ada yang akhirnya diubah menjadi KUHPerdata, KUH Pidana, dan lain-lain.

Indonesia juga menggunakan sistem hukum adat. Sistem Hukum Adat adalah sistem hukum terlama di Indonesia bahkan jauh sebelum Indonesia merdeka. Sistem Hukum Adat tumbuh dan berkembang dalam masyarakat, hukum yang dibuat, dihormati, dijaga dan dijadikan sebagai wewenang tertinggi. Ketika seseorang melakukan kesalahan, maka hukum yang hidup di masyarakatlah yang akan menghukumnya. Begitupun dengan Sistem Hukum Islam, tidak bisa dipungkiri islam adalah mendominasi penduduk Indonesia, dengan demikian penduduk muslim tersebut bahkan sebelum Indonesia merdeka sudah patuh dan tunduk pada perintah dan larangan serta menjalankan Hukum-Hukum Islam yang tertuang dalam kitab dan hadis.

\section{Perbandingan dan Perubahan Sistem} Hukum Menuju Jati Diri Suatu Negara

Lawrence M. Friedman mengemukakan 3 (tiga) unsur sistem hukum, yaitu legal substance (substansi atau materi hukum), legal structure (kelembagaan hukum) dan legal culture (budaya hukum). Elemen pertama berupa keseluruhan aturan (kaidah) dan asas hukum. Elemen kedua menunjuk pada keseluruhan organisasi, lembaga-lembaga dan pejabat-pejabatnya, yang meliputi badan-badan legislatif, eksekutif, dan yudikatif dengan aparat-aparatnya seperti birokrasi pemerintahan, pengadilan, kejaksaan, kepolisian, dan dunia profesi seperti advokatur dan kenotariatan. Sedangkan unsur atau elemen ketiga merupakan unsur aktual yang menunjuk pada keseluruhan putusan ataupun perilaku yang berkaitan dengan unsur pertama. ${ }^{13}$

Ada beberapa alasan kenapa sistem hukum dapat berubah, yakni karena:

1. Perubahan dan pergeseran sebuah nilai ideologi suatu bangsa

2. Keinginan pengusa dalam membentuk suatu tatanan bernegara

3. Keinginan politik internasional atas suatu negara

4. Keinginan kuat masyarakat karena faktor ekonomi, politik, sosial, dan lain-lain.

Turki adalah negara pembatas antara Asia dan Eropa, walaupun demikian Turki semenjak dipimpim oleh Mustafa Kemal maka menjadikan Turki lebiih condong pada hukum-hukum Eropa, sehingga tidak heran ketika Turki dikelompokkan masuk dalam sistem hukum pada keluarga Eropa Continental. Sejarah mencatat bahwa turkipernah berjaya selama 6 (enam) abad, bahkan Turki menaklukan beberapa wilayah Eropa dalam kekuasaan khilafah turki usmani yang saat itu justru menggunakan hukum islam dalam sistem ketatatnegaraannya, artinya bahwa sistem hukum islamlah yang pernah menguasai romawi bukan

13 Lawrence M. Friedman, 2013, Sistem Hukum, Nusa Media, Bandung. 
sebaliknya. Namuan pada tahun 1920-an hingga akhirnya turki digenggam oleh Mustafa Kemal terjadilah pembredelan/ pembusnahan sistem hukum islam secara keseluruhan.

Bahwa ketika dikenal 3 (tiga) unsur dalam sistem hukum, maka penulis mencoba menjabarkan sistem hukum Turki dari masa sejarah kebangkitan Turki, bahwa:

1. yaitu legal substance/substansi/materi hukum, bahwa Turki jelas memiliki materi hokum yang sejak tahun 1453-1922 Masehi oleh pemerintahan Kekaisaran Utsmaniyah Berjaya dan memimpin di sebagian belahan Eropa dan mempengaruhi sebagian Asia dengan Hukum Islam, dengan sistem pemerintahan Islam.

2. Struktur yang dimaknai sebagai kelembagaan negara seperti eksekutif, yudikatif, dan legislatif dibangun dalam sistem pemerintahan kekholifahan Islam, maka pemerintahan dipimpin oleh kholifah/ pemimpin dalam terminology Islam dan dibantu para pakar hukum yakni para alim ulama sebagai pemutus kebijakan suatu kasus.

3. kulture dimaknai dengan budaya hukum, maka di Turki suka tidak suka, mau tidak mau, penduduk musllim 90\% lebih tersebut sudah sepanjang sejarah menggunakan, memiliki dan menghidupan nilai-nilai hukum Islam, namun atas propaganda yang dilakukan pihak sekuler maka menjadikan Turki sebagai negara jajahan ideologi untuk jauh dan berpisah dari Hukum Islam. Sedekar contoh dalam hukum publik Turki dahulu ketika di bawah kekuasaan Kemalis dilarang membuat lembagalembaga keagamaan, dalam hukum privat sistem poligami dilarang, jilbab dilarang, Adzan menggunakan bahasa Turki, dan lain-lain.

Gambia adalah satu negara yang secara terbuka dan nilai cukup berani pada masa kekinian untuk mendeklarasikan negaranya sebagai negara Islam, juga berani menghentikan sistem Colonial dalam negaranya. Gambia memiliki latar belakang yang hampir sama dengan Turki, namun memiliki sejarah dan sistem hukum yang berbeda. Gambia cukup lama dijajah Inggris, kemudian Gambia menyerah dan harus mengikuti kemauan Inggris agar dimasukkan dalam negara persemakmuran Inggris dengan kepala negara Ratu Elizabet, maka secara otomatis Gambia tunduk pada Sistem Hukum Inggris yakni Anglo Saxon. Sistem hukum Inggris di Gambia adalah bagian dari sistem hukum yang dijalankan atas prakarsa politik kekuasaan semata.

Atas ketidakmampuan Gambia bertahan dan berada di bawah naungan Colonial maka pada bulan Oktober 2013, Gambia menarik diri dari Britania Raya, hingga akhirnya beberapa hari lalu yakni pada 13 Desember 2015 oleh Presiden Yahya Jameh, Gambia mendeklarasikan sebagai Negara Islam. Dengan demikian secara tidak langsung gambia sudah menolak sistem hukum inggris, yang dalam sistem hukum inggris atau anglo saxon adalah mengedepankan preceden dan memiliki hukum tidak tertulis. Sistem hukum inggris juga bernilai liberalis sehingga hukumhukum yang digunakan tentu tidak mengenal nilai ketuhanan dan religiusitas.

Pendekelarasian Gambia menjadi negara Islam bukanlah tidak didukung oleh kultur yang ada pada negara tersebut, Gambia memiliki 95\% umat Islam bermazhab Sunni, dengan demikian masyarakat kehidupan adalah sesuai dengan nilai-nilai religiusitas yang dipahami mayoritas penduduk Gambia. Bahwa faktor agama, ideology sangatlah berpengaruh terhadap tatanan Sistem Hukum Gambia untuk menjadikan Gambia sebagai Negara Islam yang seutuhnya sesuai dengan sejarah Gambia sendiri.

Bagaimana dengan negara kesatuan Indonesia? Indonesia juga memiliki mayoritas penduduk muslim sama seperti Turki dan Gambia. Namun yang membedakan adalah bukan berarti Indonesia memiliki keberanian yang sama dengan Gambia, dan Turki, hukum Indonesia adalah berdasar Pancasila, maka keragaman adalah keniscayaan di indonesia. Sistem hukum Indonesia adalah campuran dari Sistem Hukum Adat, Islam dan Eropa Continental, artinya indoensia menganulir 3 (tiga) sistem pada satu negara.

Sistem Hukum Islam misalnya, sangat jelas ketika kita lihat pada Kompilasi Hukum Islam, 
yang dijadikan rujukan oleh semua pengadilan agama, lembaga-lembaga Islam yang sah di mata undang-undang seperti Bank Syariah, bahkan di beberapa daerah menunjukkan kekhasannya dengan menerapkan peraturan daerah syariah adalah bagian dari pada pembuktian Sistem Hukum Islam adalah bagian dari kehidupan indonesia.

Sedangkan pada sistem hukum adat, Indonesia tidak mampu berkutik ketika suatu kasus oleh lembaga adat sudah dihukum, maka negara tidak patut dan haruus menghargai keputusan kepala adat setempat, adanya masyarakat Samin, Dayak, dan lain-lain adalah bukti konkrit negara menghargai dan menghormati kehidupan Sistem Hukum Adat di Indoensia. Ketua Mahkamah Agung Amerika Serikat ke 14 Earl Warren (1891-1974) pernah menjelaskan dengan lugas di depan peserta pertemuan ahliahli hukum dunia (World Peace Through Law) 1963 di Athena Yunani bahwa: ${ }^{14}$

" di dinding ruang tempat kami menyidangkan perkara-perkara yang di putus oleh Mahkamah Agung, terpahat lukisan/lambang para tokoh pembangun hukum dunia. Kami susun sedemikan rupa, sehingga di sebelah kiri dinding ada nama-nama seperti Menes (mesir), Hammurabi (Babylon), Musa dan Salomon (Israel), Lycurgus, Solon dan Draco (Yunani), Confius (Cina) dan Augustus (Roma) sebagai sembilan tokoh pembangun hukum yang hidup sebelum masehi. Sedangkan nama-nama seperti Justisianus (Roma), Muhammad (Islam), Charlemagne (Jerman), King Jhon dan Black Stone (Inggris), Saint Louist dan Napoleon (Prancis), Hugo Grotius (Belanda) dan Marshall (Amerika Serikat) berada disebelah kanannya yang diletakan sebagai sembilan tokoh pembangun hukum dunia yang hidup sesudah masehi. Dan selalu setiap ketika kami bersidang termasuk ketika mendengarkan argumen-argumen para

14 Busthanul Arifin, Hukum Pidana (Islam) Dalam Lintasan Sejarah, Dalam Pidana Islam Di Indonesia: Peluang, Prospek Dan Tantangan, Pustaka Firdaus, Jakarta, 2001, HIm 34 pengacara dan memutuskan perkaraperkara, tokoh-tokoh pembangun hukum dunia itu seakan-akan memandang kebawah sedang memperhatikan kami dan tak jarang kami yang menengadah ke atas kepada mereka untuk mencari ilham dalam memutus perkara.

\section{KESIMPULAN}

From discussion above author conclude:

a. Turkey, Gambia, and Indonesia are states that apply principles of Islamic legal sistem as their legal sistem partially and not revolutionary.

b. Islamic legal sistem is one of recognized and applied legal sistem that classified into one of family of last long legal sistem in the world.

c. Legal sistems must not be applied in accordance with colonization, commonwealth states, and political interest. On the other hand the truth legal sistem must be applied in accordance with society needs, living value or norms, history, ideology and in line with the order of statehood. In other word, in line with the title of this paper, state that legal sistem is crucial factor of state identity. 


\section{DAFTAR PUSTAKA}

BusthanulArifin, Hukum Pidana (Islam) dalam Lintasan Sejarah, dalam Pidana Islam di Indonesia: Peluang, Prospek dan Tantangan, Pustaka Firdaus, Jakarta, 2001

Erik J. Zurcher, Turkey, A Modern History, alih bahasa oleh Karsidi Diningrat R, Sejarah Modern Turki, PT Garmedia Pustaka Utama, Jakarta, 2003

Lawrence M. Friedman, Sistem Hukum, Nusa Media, Bandung, 2013

Mardani, Hukum Islam Pengantar IImu Hukum Islam Di Indoensia, Pustaka Pelajar, Yogyakarta, 2015

Michael Bogdan, Pengantar Penbandingan Sistem Hukum, Bandung, Nusamedia, 2010

Mohammad Daud Ali, Hukum Islam: Pengantar IImu Hukum dan Tata Hukum Islam di Indonesia, Jakarta, Rajawali Pers, 1990

Rony Hanitijio Soemitro, Metodologi Penelitian Hukum dan Juri Metri, Ghalia, Jakarta, 1998

Sistem Hukum Indoneisa, Prinsip-Prinsip Dan Implementasi Hukum Di Indoensia, Ilham Bisri, PT Raja Grafindo Persada, Jakarta, Tahun 2004

Soerjono Soekanto, Pengantar Penelitian Hukum, UI Press, Jakarta, 2005

Sistem Hukum Indoneisa, Prinsip-Prinsip Dan Implementasi Hukum Di Indoensia, Ilham Bisri, PT Raja Grafindo Persada, Jakarta, Tahun 2004

Sukarno Aburaera Dkk, Filsafat Hukum Teori Dan Praktik, Kencana, Jakarta, 2014

http://www.hukumonline.com/berita/baca/t53a2eb91bd3ce/prof-dr-jan-michiel-otto--brahli-hukumindonesia-harus-sering-kaji-putusan, accesed on 17 Desember 2015

http://yusril.ihzamahendra.com/2007/12/05/hukum-islam-dan-pengaruhnya-terhadap-hukumnasional-indonesial, Accesed on Desember 19, 2015

http://m.news.viva.co.id/news/read/710631-alasan-gambia-jadi-negara-islam, Accesed on 14 Desember 2015

https://chamzawi.wordpress.com/2008/07/26/islam-di-gambial, Artikel tersebut telah dimuat dalam Majalah AMANAH No. 57, Th. XVIII, Desember 2004 / Syawal - Dzulqa'dah $1425 \mathrm{H}$. Accesed on14 desember 2014 